\title{
How Do We Teach Our CLIL Teachers? A Case Study from Alcalá University
}

\author{
Mónica Olivares Leyva y Carmen Pena Díaz \\ Universidad de Alcalá
}

Received: 28 November 2011 / Accepted: 11 May 2012

ISNN: $1697-7467$

\begin{abstract}
CLIL has gained prominence in the field of Second Language teaching in Spain due to the complex challenges the educational system has to face. In Madrid, amongst other training schemes, Secondary school teachers can attend English language courses at Madrid public universities in order to improve their level of English to pass the obligatory exam, which qualifies them to teach in the regional government's CLIL project. Although CLIL has been placed at the centre of the intellectual debate, little attention has been given to the study of this linguistic training phase. This paper aims to contribute to fill this gap by examining the training programme at Alcalá University hoping to revise the perceptions of the agents involved in this type of courses for bilingual teachers.

Keywords: CLIL, secondary education, Second Language Acquisition, communicative approach, teaching assessment.
\end{abstract}

\section{La formación de profesorado AICLE. Un estudio de la Universidad de Alcalá}

RESUMEN: AICLE ha ganado importancia en el ámbito de la adquisición de segundas lenguas en España debido a los complejos desafíos a los que el sistema educativo tiene que enfrentarse. En la Comunidad de Madrid, entre los distintos programas de formación existentes, el profesorado de secundaria puede asistir a cursos de inglés en las universidades públicas madrileñas con el propósito de superar la prueba de acreditación para formar parte del proyecto "bilingüe". Aunque AICLE se haya situado en el centro del debate intelectual, se ha prestado poca atención al estudio de esta fase de formación lingüística. En este sentido, este trabajo pretende contribuir a cubrir este vacío examinando el programa formativo en la Universidad de Alcalá mediante la revisión de las percepciones de los agentes implicados en la formación lingüística de los profesores bilingües.

Palabras clave: AICLE, educación secundaria, adquisición de segundas lenguas, enfoque comunicativo, evaluación docente.

\section{Introduction}

The study of the implementation and development of the CAM Bilingual Project has attracted much critical interest in the last years. Ana Llinares and Emma Dafouz have observed that CLIL studies in Madrid show important endeavours to assess the Bilingual Programme at all educational levels and from different research lines: 
Following Dalton-Puffer and Smit's distinction between CLIL research projects at the macro or micro level, and product- or process-oriented, this chapter has shown that CLIL research in Madrid covers all four approaches. Thus, at the primary level, the UAMLESC project focuses both on process and product at the micro level, as it studies teachers' and learners' spoken production in the classroom, from a cross-sectional and a developmental perspective. Both the UAH project and the ProCLIL project focus mainly on teaching and learning processes at the macro level, as they evaluate programme implementation and development. As regards secondary and tertiary levels, research projects have focused on both process and product at the micro level, with analysis of the language of the disciplines and teacher cognition in the UAM-CLIL, and the discourse patterns in teacher discourse in the UCM-CLUE. Finally, the MIRCo project approaches multiculturalism and multilingualism in school contexts, mainly at a macro level. $(2010: 110)^{1}$

We are particularly interested in efforts addressing the issue of CLIL teacher's language and didactic training, as researchers have identified that important measures have to be taken in order "to improve their English language competences and, more specially, to acquire knowledge about structures and vocabulary related to the subjects they teach, classroom language in general" (Pena and Porto, 2008:159).

As regards the Madrid educational authorities' response to CLIL teachers' demands, Llinares and Dafouz have confirmed that the regional government also takes into consideration the distinction between primary and secondary levels:

One of the challenges of CLIL education at the secondary level, in contrast to primary education, concerns teacher profiles. While teachers in primary education have a dual profile (content and language) most teachers in secondary are content experts with certified knowledge of the target language. Therefore, some of the greatest efforts from the administration are focused on both ensuring teacher competence in the foreign language as well as raising their awareness of the specific language demands and characteristics of the different subject disciplines. (2010:100)

In relation to the regional administration's initiatives taken in making sure that future CLIL teachers in secondary education develop appropriate competence in the English language, it should be noted that the Secondary Teacher Language Training Programmes began to be implemented in 2009. In this respect, one year before the first secondary schools took part in the CAM bilingual project, in the academic year 2010-2011, the Directorate for the Quality in Teaching in Madrid organized English language courses for secondary school teachers willing to participate in the Bilingual Programme. ${ }^{2}$ Courses are now taught at six

${ }^{1}$ For more detailed information on CLIL research projects implemented in Madrid see Llinares and Dafouz's chapter "Content and Language Integrated Programmes in the Madrid Region: Overview and Research Findings" published in CLIL in Spain: Implementation, Results and Teacher Training (2010).

${ }^{2}$ As regards the number of bilingual secondary school in the Autonomous Community of Madrid, 32 centres became part of the project in the academic year 2010-2011. The same number of schools has also joined the CAM bilingual project in the present academic year 2011-2012. 
public universities of the Autonomous Community of Madrid since 2009 to present: Alcalá University, Autónoma de Madrid University, Complutense University, Rey Juan Carlos University, the Technical University of Madrid and Carlos III University of Madrid. ${ }^{3}$ Courses, from A2 to B2, are held throughout the academic year -autumn and spring courses-, but also in the holiday period, so that secondary school teachers do not have teaching duties and thus become fully involved in the learning process. All secondary school teachers can enrol on these courses, with the exception of professors and school teachers who are specialists in English. Trainees are Geography, History, Science, Physical Education, Music or Art full-time teachers with at least two years experience. Most of them are "funcionarios de carrera", i.e. permanent teachers, but also "interinos", i.e. substitute teachers, can join the course. Regular attendance is a necessity for academic success; therefore it is compulsory for students. The regional government establishes the course duration, specifying that learners have 48 contact hours and 52 hours of extra activities. Similarly, the student number is determined by the government of Madrid. Consequently, two trainers, who must be university lecturers, are in charge of a 15-20 student classroom. The administration also orders that courses be taught entirely in English while implementing a communicative methodology. It is important to emphasize that the administration particularly wants universities to only train teachers linguistically, i.e. they specifically mention that no methodology or subject-specific training is given. Universities thus organise instrumental language courses for this project. It should also be noted that a placement test is carried out before classes start for placing students appropriately. ${ }^{4}$ Given that misplacement is especially costly for a language course, Alcalá University takes an additional measure. In this sense, to ensure that every student is at the appropriate grade level the placement test cited above is combined with the experienced training teachers' observations who in the first week decide if changes are required. As far as the teaching material is concerned, the regional administration establishes that a textbook is mandatory for all courses at the different universities. In this respect, New English File, published by Oxford University Press, has been considered suitable at Alcalá University for the successful implementation of the communicative approach for all levels. It is a package that includes the traditional student's book and workbook as well as a home study CD-ROM and access to a web site for students to have independent practice and revision with the help of games, interactive exercises, extra listening and downloadable material. With respect to course evaluation, it should be mentioned that instructors grade out of $100 \%$ with a passing grade of $50 \%$. The components of the final grade are the following:

- 20\% Participation (includes daily activities and homework)

- $20 \%$ Progress test (mid-course)

- $20 \%$ Oral exam

- 40\% Final exam

${ }^{3}$ For more information about these courses check http://gestiondgmejora.educa.madrid.org/ planingles2011/

${ }^{4}$ The placement test is only compulsory for students who enter the English language course for the first time. Learners who have previously enrolled on any of the courses offered at the universities participating in the language programme are exempt from taking the placement test. 
During the last week of the course, a satisfaction survey is carried out to obtain feedback from students. After classes have ended, certificates are given to learners who have successfully completed the course. Appropriate course implementation is supervised by a coordinator, also a university lecturer. The course coordinator has to deal with all administrative matters related to registration, placement and survey tests and certification, as well as attendance to meetings held between the different coordinators from the participating universities and the person responsible for the courses in The Directorate for the Quality in Teaching in Madrid.

The fact that Alcalá University's language training programme has been implemented for over two years makes it convenient to analyse and assess the effectiveness of the main teaching components that make up courses. To this end, we have carried out a study that aims at finding out the main factors that affect the development of language training at the different levels taught. With this objective in mind, the results will be presented and discussed as well as the main conclusions that have been drawn.

\section{THE STUDY}

The fact that the teaching variable is an important phenomenon that helps understand the teaching-learning process made us design a questionnaire for training teachers in order to account for the perceptions of the instructors regarding the validity of the English language courses at Alcalá University (see appendix). ${ }^{5}$

Likert scale questions were combined with open-ended questions as we aimed at offering respondents the possibility to express their feelings and attitudes with their own words as well as bringing up new issues. Training teachers were asked to answer sixteen questions. The first set of items dealt with the course organisational aspects because we were really interested in finding out their opinions on timetables and number of trainers and trainees per class. The Likert scale questions were used to have instructors' views on these issues, as they had to indicate their agreement on a five-point scale (i.e. 1: strongly disagree; 2 : slightly agree; 3 : agree; 4 : partially agree; 5 : strongly agree) with four statements regarding course organisation (questions 2, 3, 4 and 5). An open-ended item was added to complement the Likert scale questions, so that respondents could express extensively their views on course duration (question 15).

We also wanted to know if training teachers were happy with the communicative approach. For this reason, an open-ended question was included to have their opinions on the advantages and disadvantages of the teaching methodology (question 8). Within this communicative context, instructors were asked to specify which students' skills were greatly improved (question 11), and assess which supplementary teaching materials were used (question 9). To be exact, we wanted to know if the application of the communicative approach was successful with the help of the mandatory textbook or, on the contrary, trainers felt the need for supplementary materials such as ICT. For this reason, they were required to list and rate

${ }_{5}^{5}$ The survey was designed in Spanish, therefore translation of the different items will be offered, if needed. 
the ICT resources used in the course, specifying the educational usefulness on a five-point scale (i.e. 1: totally useless; 2: slightly useful; 3: useful; 4: very useful; 5: most useful). Added to that, the course evaluation was also looked at on the questionnaire. An open-ended question was included to gain knowledge of training teachers' choice of assessment tools (question 10). We were particularly interested in establishing not only effectiveness, but also detecting if any evaluation instrument failed to assess trainees. Besides, we were curious about trainers' confidence to reach course objectives in the unique context these courses take place at: taught entirely in English by teachers for teachers in a very short period of time. Therefore, training teachers were asked if they considered it necessary to have any kind of didactic training (question 13). Instructors were also encouraged to report on learners' attitude, motivation and expectations, as we were curious to know their perceptions of students' performance in these courses (questions 6 and 7). Finally, we aimed at finding out if training teachers believed that courses met students' expectations (question 14), as we already had students' views on this issue (Pena and Olivares, 2011), and thus we could compare and contrast both sides of the topic. ${ }^{6}$

With all these variables under consideration, we assumed that we could establish the main factors that affect the implementation of English language courses at Alcalá University. Nevertheless, two more open-ended questions were added to get information about the advantages of these courses as well as the obstacles that may also appear (questions 12 and 16). The idea behind these items was to give instructors the opportunity to comment on any relevant aspect they could not express in previous questions.

\section{Results}

In this section we present the results obtained according to three main areas of interest in language training programmes: organizational aspects, relevance of the methodology and evaluation criteria, and description of the main needs and problems identified by instructors.

As regards organizational aspects, when training teachers were asked about the appropriateness of the timetable, it was generally agreed that the amount of contact and non-contact hours allowed the successful course implementation. One instructor admitted in an openended question, however, that the increase in the course duration would be advantageous to obtain better results. Regarding the number of instructors and students per class, it was also considered appropriate. Nevertheless, one trainer made an observation on this issue in an open-ended question, suggesting that the number of students made his teaching somewhat difficult. In brief, instructors assured that the organisational aspects were quite pertinent for students to reach learning objectives, although the course extension was also taken into account as well as the reduction in student number.

\footnotetext{
${ }^{6}$ We had the opportunity to disseminate the results of students' questionnaires in the round table "Training Teachers for Bilingual Education: Where Do We Stand and Where Do We Need to Go?" during the XXXV International Conference of the Spanish Association for English and American Studies (AEDEAN) that took place at the Autonomous University of Barcelona in November 2011. Ma Luisa Pérez Cañado from Jaén University and Carmen Bretones Calleja from Almería University also participated in the session.
} 
As far as the instructors' assessment of the communication approach is concerned, it should be noted that training teachers did not mention any difficulty when delivering courses entirely in English. It was noticeable to find out, however, that most instructors noted down the same problem in the implementation of this methodology. In this respect, it was generally claimed that there was no group homogeneity in the classrooms and, curiously, it happened at all levels. In this sense, it was argued that there were students who lacked the necessary oral skills to interact inside the classroom context. This was in itself interesting since it points out one important drawback in the application of the communicative approach in these English language courses at all levels. This result seemed quite striking because the placement test had been previously done to place students in the correct class.

Trainers' remarks on the teaching resources used in class were also highly interesting. Except one instructor who commented the use of the virtual classroom Blackboard for noncontact hours, it quickly became apparent that courses followed the same pattern as traditional teaching, as instructors used the textbook with the support of the corresponding CD-ROM. ${ }^{7}$ Therefore, the fact that most training teachers did not use ICT during the course and did not express drawbacks in relation to the exclusive use of the mandatory textbook could mean either that they are not used to other type of material than the traditional textbook, or that the teaching material easily adapted to teach secondary school teachers, so that both training teachers and students felt comfortable with them. As a matter of fact, two instructors explained that the mandatory textbook represented an undoubtedly helpful teaching resource, because it facilitated them the preparation of their classes. Both instructors also acknowledged that the use of the textbook was equally advantageous to their students, as they felt more confident. As a drawback one of the training teachers emphasized, however, that pressure to cover all the content of the textbook implied two important disadvantages to students. Firstly, he claimed that there was not time left to study particular learning objects in depth and, secondly, regretted not having enough time either to make use of complementary teaching resources. From this instructor's opinion we may infer that the non-use of ICT could not have been a training teachers' choice, but rather a circumstance imposed by the time limitations of the course characteristics. Adding to that, the same instructor underlined that the textbook itself failed to teach the communicative approach in two different aspects. On the one hand, he alleged that the teaching resource offered a superficial treatment of some linguistic concepts and, on the other hand, argued that the textbook did not present enough activities to improve students' speaking skill as expected. In summary, the central position of the textbook in the syllabus helps complete course objectives, but it may not allow instructors to overcome hindrances to the learning process. It is also striking that students, who are teachers themselves, find that the material, a textbook, is ideal, as this would not precisely be considered the best tool for a modern language class or would comply with the CLIL methodology.

${ }^{7}$ The learning and teaching experience in the use of Blackboard has been analysed in a different research which is foreseen to be published by Cambridge Scholars Publishing under the provisional title "The Use of ICT for Language Teaching in Secondary Teaching Training Programme" in the volume Spanish CLIL in Action: Voices from the Classroom. 
Concerning course evaluation it should be mentioned that training teachers gave a full account of the assessment instruments used to measure students' learning outcomes: class participation, assignments, oral presentations related to their speciality, mid-term exam, final oral exam and final written exam. It was interesting to note that four instructors did not comment on the grading system, what suggested that they were satisfied with the percentages attributed to each part of the final grade and with the passing grade. In fact, one instructor observed that she was glad that the same grading system had been recently established for all levels in July 2011. On the contrary, one training teacher complained about the percentages assigned to the oral and final exams, specifying that they were too high for students. Besides, the instructor recommended lowering the percentages of the exams mentioned above, while increasing the participation percentage. These results indicated thus that courses had lacked consistent assessment across levels for two years but, at the same time, it also meant that corrective measures had been taken to solve the imbalance. Besides, although the grading system was judged positively by most training teachers, it is also true that a dissenting opinion was expressed by one instructor.

Although attendance was mandatory and thus an important evaluation tool, it was noticeable that training teachers did not mention that students failed because of unjustified absences. This result suggested that secondary school teachers showed high motivation and positive attitude about the course that, as one training teacher observed, had favourable repercussion on their performance. One trainer claimed, however, that students sometimes could not attend classes -although they strongly wanted to- due to their teaching duties. In this respect, the instructor pointed out that their secondary school centres scheduled meetings without taking into consideration the English language course timetables. Although absences were justified, the training teacher emphasized that students' learning process was, particularly in an intensive course format, significantly interrupted. In the teacher's response we perceived that there was an evident lack of coordination between educational centres and English language courses that may have had a negative effect on the course development.

When evaluating trainers' level of satisfaction in the implementation of the language programme, it should be mentioned that courses were assessed, as a whole, as highly positive, as responses ranged between 4 and 5, when expressing their agreement with the statement "In general, I am satisfied with the experience of having taught this course" (question 7). This result curiously coincided with students' level of satisfaction, as has been shown in an analogue research previously cited in the introductory section of the article (Pena y Olivares, 2011). The coincidence clearly reveals that courses are developing satisfactorily from the point of view of students and instructors. In fact, teachers agreed that they did not need further training or information to teach students. Furthermore, training teachers were asked if, in their opinion, courses had met learners' expectations. Respondents agreed that students' communicative skills had improved, though one instructor specified that the course duration was insufficient for learners to have enough practice to develop oral skills as expected. It was also interesting to note that one training teacher noticed that these courses offer additional advantages to learners other than linguistic improvement. In this respect, the instructor emphasized that trainees who had not studied English language for a long time were among the learners who took full advantage of courses, regaining their interest in learning a foreign language. Moreover, the training teacher stated that students restored, above all, confidence in expressing themselves in English in public. In addition to that, the instructor detailed that 
courses provided students with the opportunity to find out their weaknesses and strengths in using English. These results reflect, in brief, two important characteristics of the student's profile that enrols on these courses: secondary school teachers who stopped learning English long time ago and who are likely to be fearful to speak in English.

Trainers also noted down that students showed strong motivation and made great effort in the achievement of course learning objectives. Taking into account that instructors were not asked to give opinions on these aspects, it was surprising that all made spontaneous remarks highlighting their great learning enthusiasm. The fact that the level of secondary school teacher's motivation is high is in line with the conclusion of Fernández et al. (2005) who found similar results in a study conducted among primary school teachers in the Community of Madrid before the bilingual programme started in 2004.

As regards training teachers' perceptions of the most difficult aspects for students, it was acknowledged that courses lacked adequate time planning. To be more exact, instructors referred to the fact that a student who obtained a certificate may have to wait between six months and one year to attend the following course. We would tentatively say that two main causes may have contributed to this situation. On the one hand, a course is cancelled in case the student number does not reach the minimum required. On the other hand, we believe that the current economic crisis may have become a important factor for course interruption, as autumn courses that were going to take place this year, for example, have been cancelled.

\section{Discussion}

Training teachers are, generally speaking, satisfied with the implementation of the language training courses for secondary school teachers. In the first part of the questionnaire -from question 2 to 7 - instructors coincided in the appropriateness of these courses, which indicates that the election of the course structure was an adequate choice done by the regional administration. As we proceeded in the analysis of the questionnaire, however, it seemed that the first excellent impressions of the first items were later toned down by a deeper reflexion, as was shown in the open-ended questions. Consequently, results indicate that courses are of great benefit for students and that there are no sources of frustration for instructors, only difficulties that, as we will attempt to show below, can be easily overcome.

If training teachers are considerably satisfied with the general organisational aspects of the language courses, it is clear that the number of contact hours and extra hours allow the successful development of the courses. Notwithstanding, we cannot neglect that recent studies have shown that their own language proficiency in CLIL education is among the main worries teachers have before working in bilingual schools, as recently shown by Pena and Olivares (2011) and, what is more important, when they are teaching CLIL classes, as demonstrated by Halbach (2010) and Fernández and Halbach (2011). Taking these studies into consideration, we are truly convinced that expanding these courses in time is enormously recommendable. Not only because students claim that they need more contact with the English language, but also because trainers and trainees would be able to work the same content in a less stressful manner. What is more, the fact that both training teachers and students coincide in pointing out the lack of continuity between courses also demonstrates 
that educators are demanding solid course continuity. We further put forward for consideration that an academic year would make it possible for instructors to make use of ICT in and out of the classroom.

Results from this study also show that students' attitudes and motivation play a major role in the successful development of the English language courses. Training teachers were noticeably proud of learners' positive attitude in class. Additionally, the fact that courses were entirely in English was not reported by instructors as an affective factor that caused lack of motivation, even for students in lower levels. Thus we may infer that learners' positive attitude is one of the main driving forces that enables students to overcome difficulties in the duration of the course. If students show strong motivation, we truly believe that the problem of coincidence between secondary school centres' meetings and courses' contact hours has to be solved. We strongly recommend that educational centres collaborate and support future CLIL teachers by scheduling meetings on a time different from the English language courses. In this way students could make the most of classes and the involuntary absences would not influence negatively in the learning process.

It is a fact that the regional administration and public universities working in this programme's decisions on the linguistic methodology are satisfactory, as most instructors rely on the communicative approach and the usefulness of textbooks, although it would be wise to allow instructors to choose the material they prefer. Besides, training teachers' decisions to take advantage of the student profile is a factor of success. In this respect, oral presentations are of great importance, as they have proved effective in providing students with confidence in speaking in public, as they are specialists in the discipline they are talking about. However, evidence of non-homogeneity in the classroom when implementing the communicative approach affects negatively the development of these courses. Although instructors aim at offering training for written and oral communicative skills, it is a fact that a small number of students in all groups do not show the same abilities as the rest of the class, as far as oral interaction is concerned. As we see it, results clearly indicate that the placement test does not work satisfactorily. Besides, it means that the level changes that usually take place in the first week may not help either. It seems that a one-week period is not enough for teachers to take decisions. Thus we believe that the observation period should be extended one more week. This measure can be taken in autumn and spring courses; however, time constraints make it non-viable in summer courses, as they only last four weeks. We therefore suggest including a more reliable way of assessing individual abilities for all courses that allow better student placement before courses start. It would be convenient that the placement test be combined with an interview to assess students' speaking skills individually. Pair assessment would also be recommended, as candidates' skills to interact orally can be clearly shown. Taking these measures may reduce the possibilities of misplacement; however, it is evident that there will always be students who are incorrectly misplaced independently of the strategy used.

Uniformity in the course implementation is the last key factor to be mentioned. From the very moment courses started two years ago, it is evident that the regional government's emphasis has been placed on establishing the same criteria across universities, regarding organisational aspects, methodology and textbook. It should be noted, however, that less attention has been given to evaluation, as the grading system uniformity for all participants was established this year. All the same, we would like to congratulate the administration on implementing changes in order to achieve a common approach to all universities. 


\section{RECOMMENDATIONS}

Although the courses can be regarded as having a high teaching quality, we present three proposals for action taking into consideration the student and course profiles. First of all, students, being teachers themselves, could be more integrated, being allowed to organise themselves, to some extent, as to what happens in the class. We are convinced that they would make an effort to find learning resources helpful for their classmates. We believe that students' involvement in class activities would be an excellent tool for maintaining motivational level high as well as finding out what kind of language areas they feel they should have more practice to attain learning objectives.

Secondly, the fact that students take courses from level to level makes it possible for instructors to follow students' learning process. Accordingly, we believe that keeping track of students' grades with a convenient and customizable sheet can be recommendable for the correct development of the English language training. We suggest that students' records include information collected from students' interviews before courses start, keeping a record of students' communicative competence, as regards their weaknesses and strengths. Therefore, when students start classes in the following level, instructors can take advantage of students' strengths as well as working harder weak language areas. This proposal also calls for collaboration between universities. In case that a student changes from university to university, the exchange of students' records would be recommended. Added to that, it would be advisable that students' follow-up do not stop at that point, and student-teacher communication be maintained in the duration of the course. Questionnaires or learning diaries, for example, would provide trainers with an insightful account of their needs. We feel sure that student feedback would particularly help instructors to seek remedial solutions for those students needing to catch up to the level of the class. Besides, the process of reflecting can be valuable for students as well, as they would probably get more involved in the learning process. In brief, we believe that the studentsí records would help measure students' progress correctly.

Thirdly, since English language courses for secondary school teachers at public universities are relatively new in the Community of Madrid it may be a good idea to establish connections between instructors. Considering that it is generally accepted that teachers reflect on their teaching practice, if high quality courses are offered, it is important that English language instructors are given the opportunity to share teaching experiences. Therefore, we strongly recommend that regular training teacher's meetings be taken into consideration. In this sense, instructors can assess the teaching implications of the main elements that affect the English language courses and that we have identified in this study: timetable, student number per class, students' motivation and level placement as well as the ramifications of methodology and evaluation. Then, the Community of Madrid could gather results, foresee remedial measures and make decisions for inclusion in the educational practices of the language teaching programme. In brief, we believe that the interchange of teaching experience can be a crucial factor for courses to succeed.

This study was based on exploring training teachers' opinions at Alcalá University. Moving onto broader concerns, a future study of instructors' perceptions from the other public universities of the Community of Madrid may be helpful to compare and contrast the similarities and differences that may be found. 


\section{Conclusion}

Our research has generated empirical evidence for the efficiency of the Secondary Teacher Language Training Programmes, as it is a fact that no crucial teaching challenges have been identified. The slight difficulty of some students' low level of oral proficiency than the rest of the class can be overcome, if the teaching recommendations proposed in this article are taken into consideration. Although this preliminary study has contributed with some relevant insights into the English language training for secondary school teachers, the results should not be generalised since the research has been conducted only among instructors at Alcalá University. In a follow-up study we will focus on collecting, analysing and discussing training teachers' experiences at other universities that offer these courses in the Community of Madrid. All in all, though the study has shown that the English language programme is satisfactorily implemented, we expect to have raised awareness on the necessity to examine their implementation regularly.

\section{REFERENCES}

Fernández, R. Pena, C. García A and Halbach, A. (2005). "La implantación de proyectos educativos bilingües en la Comunidad de Madrid: las expectativas del profesorado antes de iniciar el proyecto". Porta Linguarum 3: 161-173, available from http://www.ugr.es/ portalin/articulos/ PL_numero3/fernandez_proyectos\%20bilingues.pdf, accessed 26 November, 2011.

Fernández, R. and Halbach, A. (2011). "Analysing the Situation of Teachers in the CAM Bilingual Project after Five Years of Implementation", in Y. Ruiz de Zarobe, J.M. Sierra and F. Gallardo del Puerto (eds.), Content and Foreign Language Integrated Learning: Contributions to Multilingualism in European Contexts. Bern: Peter Lang, 241-270.

Halbach, A. (2010). "From the Classroom to University and Back: Teacher Training for CLIL in Spain at the University de Alcalá", in D. Lasagabaster and Y. Ruiz de Zarobe (eds.), CLIL in Spain: Implementation, Results and Teacher Training. Newcastle upon Tyne: Cambridge Scholars Publishing, 243-256.

Llinares A. and Dafouz, E. (2010). "Content and Language Integrated Programmes in the Madrid Region: Overview and Research Findings", in D. Lasagabaster and Y. Ruiz de Zarobe (eds.), CLIL in Spain: Implementation, Results and Teacher Training. Newcastle upon Tyne: Cambridge Scholars Publishing, 95-114.

Olivares, M. and Pena, C. (forthcoming). "The Use of ICT for Language Teaching in Secondary Teacher Training Programme”, in M.L. Pérez Cañado (ed.), Spanish CLIL in Action: Voices from the Classroom. Newcastle Upon Tyne: Cambridge Scholars Publishing.

Pena, C. and Porto, M.D. (2008). "Teacher Beliefs in a CLIL Education Project". Porta Linguarum 10: 151-161, available from: http://www.ugr.es/ portalin/articulos/PL_numero10/11\%20 Carmen\%20Pena.pdf, accessed 23 November, 2011.

Pena C. and Olivares, M. (2011). "Training Teachers for Bilingual Education: Where Do We Stand and Where Do We Need to Go?" Round Table of the XXXV International Conference of the Spanish Association for English and American Studies (AEDEAN). Autonomous University of Barcelona. 16-18 November 2011.

Plan de Formación en Lengua Inglesa. URL: http://gestiondgmejora.educa.madrid.org/planingles2011/, accessed 11 November, 2011. 


\section{APPENDIX}

\section{ENCUESTA AL PROFESORADO SOBRE LOS CURSOS DE FORMACIÓN LINGÜÍSTICA DE LA CAM}

\section{P1. ¿Cuál ha sido el nivel del último grupo al que has impartido clase?}

Indica tu grado de ACUERDO con las siguientes afirmaciones en función de la siguiente escala:

1=Nada de acuerdo, 2=Poco de acuerdo, 3=Medianamente de acuerdo, 4=Muy de acuerdo, $5=$ Totalmente de acuerdo.

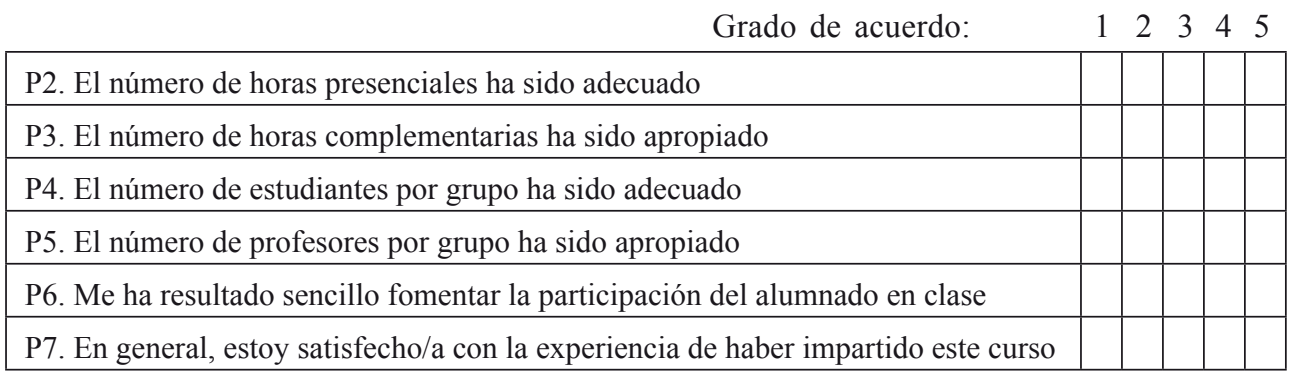

P8. ¿Qué METODOLOGÍA has empleado con tus estudiantes de la CAM? Especifícala, por favor, e incluye los comentarios que desees sobre sus ventajas e inconvenientes, $y$ sus posibles mejoras.

P9. ¿Has utilizado el apoyo de las TICs?

O Sí O No

$\mathrm{L}_{\longrightarrow}$ Si la respuesta es afirmativa, indica el nombre del recurso TIC y tu grado de satisfacción en función de la siguiente escala:

1=Nada útil, 2=Poco útil, 3=Medianamente útil, 4=Muy útil, 5=Totalmente útil Grado de utilidad: $\quad \begin{array}{lllll}1 & 2 & 3 & 4\end{array}$

\begin{tabular}{|l|l|l|l|l|}
\hline Recurso TIC: & & & & \\
\hline Recurso TIC: & & & & \\
\hline
\end{tabular}


P10. ¿Qué métodos has utilizado para la EVALUACIÓN? Especifícalos, por favor, e incluye los comentarios que desees sobre sus ventajas e inconvenientes, y sus posibles mejoras.

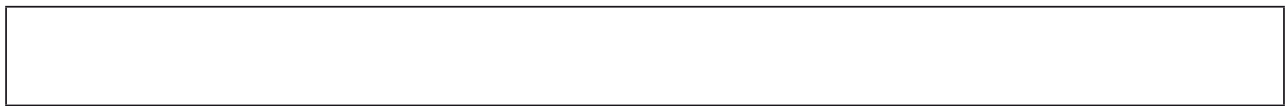

P11. Respecto a las destrezas comunicativas ¿cuáles han sido las que los estudiantes han mejorado más? ¿Y menos?

P12. En general, ¿con qué clase de ventajas y dificultades te has encontrado en el aula de inglés?

P13. ¿Crees que sería conveniente recibir algún tipo de formación/información para impartir esta clase de cursos?

O Sí O No

$\mathrm{L} \rightarrow \mathrm{Si}$ la respuesta es afirmativa, especifica qué clase de formación/información

P14. En general, ¿crees que tus alumnos han sacado el máximo provecho del curso que has impartido y que se han cumplido sus expectativas?

P15. ¿Crees que un curso es suficiente para alcanzar el nivel propuesto? Por favor comenta tu respuesta.

P16. ¿Tienes alguna otra valoración que hacer que no haya sido recogida en los apartados anteriores? En caso afirmativo, incluye los comentarios que consideres oportunos: 